\title{
REFLECTING ON PAUL'S (NON-)USE OF THE OLD TESTAMENT IN THE LETTER TO THE ROMANS ${ }^{1}$
}

\author{
Eben Scheffler \\ Department of Old Testament and ANES \\ University of South Africa
}

\begin{abstract}
In endeavouring to contribute towards a better understanding of the letter to the Romans, as well as the Old Testament, attention is paid to Paul's expressed views on the Old Testament; the centrality of the Christ event in his thinking; his use of contemporary exegetical techniques; his employment of quotations, general references and allusions to the Old Testament; his use of the LXX; his reading of the Old Testament in (and out) of context; his understanding of the law; his view of justification by faith as Paul's own creative thinking; the difference between Paul and Jesus'view of the Old Testament and Paul's non-use of the Old Testament. Concluding remarks are made about an 'empathetic' reading of the Old Testament and the letter to the Romans, accounting for both texts' true nature.
\end{abstract}

Key Words: Old Testament, Letter to the Romans, Paul, Exegetical Techniques, Hermeneutics.

\section{Introduction: Towards Understanding two Texts better}

The letter to the Romans which was in all probability written by Paul in $56 \mathrm{BC}$ in Corinth on his way to Jerusalem, is regarded by most scholars as not merely a letter but also a compendium of his thought (cf. Schnelle 2007:129-132,143-147). ${ }^{2}$ As such it had a profound influence in the history of the Christian church - at various important turning points of its history.

Many commentaries were written on the letter throughout the history of Christianity (e.g. Origin, Chrysostom, Pelagius, Abelard, Aquinas, Erasmus, Luther, Melanchthon, Calvin, Barth) ${ }^{3}$ and many commentaries have been written in the past decades by prominent scholars (cf. bibliography below). Despite these, the verdict 100 years after Paul of the

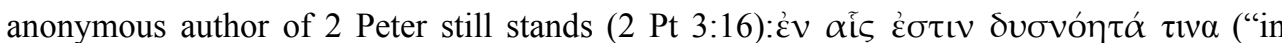
them [Paul's letters] there are incomprehensible things"). Bornkamm (1971:xxvi) in his famous book on Paul formulates as follows:

Dedicated to Prof Andrie du Toit ('der achzigjärige'), with much gratitude and appreciation, in the spirit of in necessariisunitas, in dubiislibertas, in omnibus caritas.

2 To my mind Bornkamm's (1971:98) calling the letter to the Romans 'Paul's testament' is not an apt description of the letter. Apart from Paul's expressed future plans (mentioned by Bornkamm himself), a testament or will simply does contain so much theology and ideology.

3 Listed by Reumann 2006:1283 and well discussed by Breytenbach 2011; cf. also the comprehensive list in Fitzmyer 1993:173-214. Noteworthy for the South African context is the 1861 commentary by Colenso, recently republished (ed. JA Draper, cf. Colenso 2003). 
The intellectual range of his message soared to incomparable heights which are today still unconquered. Small wonder that many readers are left gasping at his letters - loaded to the brim with a heavy cargo of thought. Many who yield themselves to his message are left feeling like a hiker in a mountainous region surrounded by steep, cloud-covered peaks, often not knowing how to continue and how to last the journey. ${ }^{4}$

Paul makes ample use of the Old Testament in the letter to the Romans - one can even say that he explains his thought by means of the Old Testament. As such it is my contention, first of all, that a systematic investigation of how Paul used the Old Testament in his letter to the Romans has heuristic value towards unravelling his complicated thought.

But, secondly, exploring how the Old Testament is used in Romans should also be done for the sake of the Old Testament itself. Since for Paul his gospel concerning Jesus Christ was central; he read the Old Testament from this perspective, most often than not out of literary as well as historical context. And because the letter to the Romans occupies such a central place in Christianity, most Christians' (and even professional theologians') views of the Old Testament are mediated and determined by Paul. One can only refer to views regarding 'law and gospel' (Luther), 'promise and fulfilment' (Calvin), and Bultmann's view of the Old Testament as 'Scheitern' in this regard (cf. 1933:148-171). Even the terms 'Old' and 'New' Testament are implicated.

To fully appreciate Paul's use of the Old Testament in the letter to the Romans, all quotations and references to the Old Testament should be intensively investigated. Having done this, constraints of space make it impossible to report on these within the scope of an article. ${ }^{5}$ My approach in what follows will be to make several statements that characterise Paul's use of the Old Testament in Romans, discussing selective examples that illuminate these statements. Ultimately, my aim is hermeneutical, hence the term 'reflecting' in the title. While Rome (no pun intended!) is burning, it makes no sense merely to count how many angels can dance on the point of a needle. Moving beyond a critical analysis of Paul's use of scripture, the serious question should therefore also be asked to what extent the reader of Romans can in the (post-)modern world still subscribe to Paul's message, as well as his (non-)use of the Old Testament in formulating it. It is hoped that in the end the reader's understanding of both the letter to the Romans, as well as the Old Testament itself will be enhanced - to the benefit of both.

\section{Paul's Explicit Reflection on the Old Testament}

Paul's own reflection on the Old Testament provides insight into his hermeneutic point

of departure which correlates with his practical use of the Old Testament.

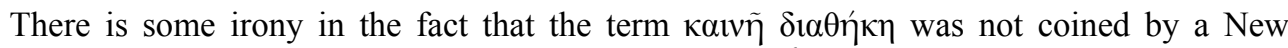
Testament author but by the prophet Jeremiah $(31: 31){ }^{6}$ whereas a New Testament author, Paul, coined the term 'Old Testament', referring not to the covenant(s) made with ancient Israel in general, but to the text. Allow me (just this instance) to quote from outside Romans. Referring to the Israelites (or Jews) reading scripture, Paul states in 2 Cor 3:14-16:

Translation slightly adapted in accordance with original German version ('mountainous region' for 'Bergwelt' instead of the translator's 'Alpine region' - so much for the role of context!), cf. Bornkamm 1970:24.

5 Cf. the extensive investigations by e.g. Michel ([1929] 1972), Ellis (1957), and in South Africa, Punt (1996, 2000).

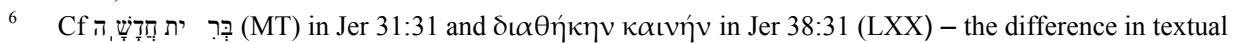
reference due to the large differences between the LXX and MT texts. 
But their minds were hardened; for to this day, in their reading of the old covenant ( $\tau \tilde{\eta} \varsigma$ $\pi \alpha \lambda \alpha \imath \tilde{\alpha} \varsigma \delta 1 \alpha \theta \eta \dot{\eta} \kappa \varsigma)$, that same veil remains on, because only through Christ is it taken away. Yes, to this day whenever Moses is read a veil lies over their minds; but when a person turns to the Lord the veil is removed.

From this text some aspects of Paul's view of the Old Testament become clear:

- According to Paul the Jews read their own scriptures wrongly. Referring to the veil that Moses put on his face (Ex 34:29-35) because his face shone too brightly after talking to God on mount Sinai, Paul applies the term 'veil' allegorically to the Jews' reading of the Old Testament. They do not discern the true meaning.

- According to Paul the veil is taken away through Christ: therefore becoming a Christian in his view enables one to read the Old Testament correctly.

- Paul also refers to 'reading Moses'. This can be taken to refer to the Pentateuch (in his day the most important part of the Jewish canon), or the Old Testament as a whole. This reflects some ambivalence of Paul's thought, to say the least. Sometimes the whole Old Testament is seen as the law which is contra the gospel (cf. previous verses in chapter 3), but sometimes the Old Testament is evaluated more positively and in broader terms (see below). If the veil is lifted, it can be positively read after all, despite being 'letters in dead stone' which leads to death.

This ambivalence we also find in the letter to the Romans, where Paul reflects directly on the Old Testament. In Romans 15:4 Paul remarks positively:

For whatever was written in former days was written for our instruction, so that by

steadfastness and by the encouragement of the scriptures we might have hope.

It is noteworthy that this verse appears in the paraenetic section of his letter. In explaining his basic tenet of justification through faith instead of the law (see below), Paul seems to characterise the whole Old Testament as $\pi \alpha \lambda \alpha i \tilde{\alpha}$, but nevertheless draws upon it in view of the Christian lifestyle. ${ }^{7}$

In discussing the 'Jewish problem, ${ }^{, 8}$ Paul's refers in Romans 9:4-5 to the Israelites as having (as is obviously expressed in the Old Testament):"the sonship, the glory, the covenants, the giving of the law, the worship, the promises, the patriarchs and (from their

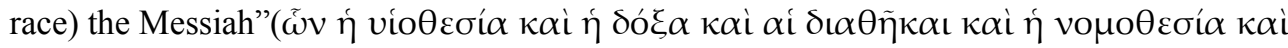

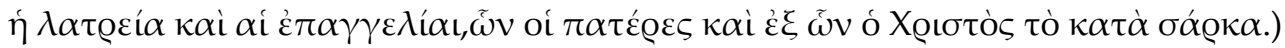

The law is here mentioned, but only as one among eight mentioned aspects, and the text thus reflects a positive broader perspective on the Old Testament. The question remains: is it broad enough? Does it reflect the Old Testament in its full diversity? And, finally, is the ideology of Romans 9-11 not that all these 'positive' aspects are of no avail if the Jews do not accept Jesus as the Christ? To this question, we will return.

\footnotetext{
In his excellent exploration of Paul's perspective on the Christian lifestyle, Du Toit (2006:190) in discussing 'loving one's adversaries' unfortunately does not mention Paul's use of Deuteronomy 32:35 (the Targum version, cf. Ellis 1957:140) and Prov 25:21-22 in Romans 12:19-20. However, he emphasises Paul's view that the love commandment (Lev 19:18) fulfils the law, but does not mention that it summarises the Ten Commandments (referred to and quoted by Paul in Rm 13:9).

8 A problem from Paul's perspective since the Jewish nation as a whole did not accept the Gospel as Paul saw it.
} 


\section{Paul's use of Contemporary (Jewish) Exegetical Techniques}

By using contemporary Jewish exegetical techniques Paul reads the Old Testament as a child of his time. These techniques allowed him to interpret the Old Testament in terms of his gospel about Jesus Christ.

Unlike the man he was preaching about and upon whose person he built his whole theology, Paul, being born and raised in Tarsus, was an educated Hellenistic Jew (cf. Du Toit 2000). As such he was not merely orally informed about the Old Testament, but also versed in its interpretation as scripture. As an exegete of his time he used several exegetical techniques employed in contemporary Judaism, although he was not bound by these techniques (Conzelmann 1976:188).

\section{Allegory}

The allegorical method (widely employed by Philo) represents the manner of interpreting a text which otherwise (when read at face value) makes good sense, in terms of a 'deeper spiritual meaning' which is then regarded to be contained in the words. The above discussion of the 'veil' in 2 Cor 3 showed how Paul employed allegory, a technique often used by rabbinic scribes (and subsequent Christianity). In Romans it is not so much used (cf. however the concept of 'justice' or 'just' becoming 'justification' in the Pauline sense, cf. Hab 2:4 and the discussion below). ${ }^{9}$

\section{Typology}

The typological method can be regarded as representing a more positive interpretation which does not deny the original meaning of the text. It notes the recurrence or comparison in the present of what happened (mostly to persons) in the past. ${ }^{10}$ Thus Moses (receiving the law at mount Sinai) is a 'type' of Christ giving the new law in the sermon of the mount. Paul devotes a whole chapter ( 25 verses in chapter Rm 4, cf. especially verse 3,9 and 16) to explain how Abraham (cf. Gen 15:6) was an example or (proto)type of a believer that was justified by faith and not works. ${ }^{11}$ Typology also occurs in chapter 5 (cf. next paragraph).

\section{A minori ad maius (Generalisation)}

This method also does some justice to the original text. In Romans 5:12-21 Paul compares

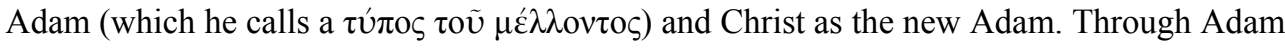
sin came into the world unto all people, with condemnation and death as the result, but through Christ many receive justification with grace as the result - which is much more. This constitutes typology, but even more. Reasoning a minore ad maius ('from the smaller to the greater'), Paul combines two techniques which are thus simultaneously used. The

9 Outside Romans allegory is to be found in Gal 4:21-31 (cf. Gen 16:15; 21:2,9), 1 Cor 5:6-8 (cf. Ex 12:15,19),1 Cor 9:8-10 (cf. Deut 25:4).Cf. Ellis 1957:51-54; Barrett 1970:391-392; Scheffler 1991:103-104. For the use of allegory in early Christianity (and its dangerous application to poverty). See Le Roux 1991:90-101.

10 Ellis $(1957: 127)$ refers to Gehard's distinction between allegory and typology: "Typology consists in the comparison of facts. Allegory concerns itself not so much in facts as in their assembly, from which it draws useful and hidden doctrine." Typology therefore maintains some kind of historical awareness.

11 Romans 4 is regarded by Barrett (1970:393) as an example of analogy (gezerahsawah). Since analogy supposes a greater extent of historical awareness, I would rather (with Hahn 2011:197) judge Rm 4 to be an example of typology because Paul did not do sufficient justice to neither the concepts of ãÈ àiii(trust)in Gen 15:6 (cf. Deut 24:13, Ps 106:30-31 and the discussion in Westermann 1981:263-265). 
result is a functioning on two levels. One man's sin was generalised to all men's sins. One man's righteous life (interestingly Jesus' death is not mentioned here) is generalised to many people's justification. But, on the second level, the latter positive generalisation is

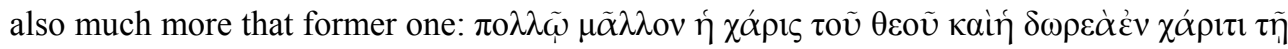

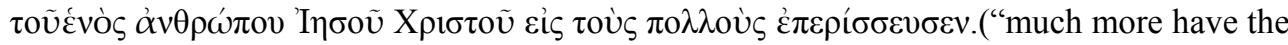
grace of God and the free gift in the grace of that one man Jesus Christ abounded for many", Rm 5:15). One can also conclude that the motif of the church as the 'true Israel' (cf. $\operatorname{Rm} 9: 6)$, the new covenant versus the old one, and justification through faith versus the law, are all examples of the outcome of this interpretative method (cf. also 11:15, 26-32).

\section{Qumran pesher-exegesis}

Interesting is Paul's peculiar use of this method, which implies that it probably was used more widely than the Qumran community (see Barrett 1970:386-388,392; Scheffler 1991:104-105). In this method whatever is said in the text is directly interpreted in terms of the time of the exegete, without any regard for the original context. It abounds in the Qumran commentary on Habakkuk. The biblical text is quoted, followed by the word pesher (= interpretation), where after the interpretation is given.

Habakkuk 2:15 would then be interpreted as follows:

Woe to him who makes his neighbours drink of the cup of his wrath, and makes them drunk, to gaze on their shame!

Pesher: It refers to the evil priest who persecutes the teacher of righteousness. 10:6-8:

The classical example from Romans is Paul's use of Deuteronomy 30:12-14 in Romans

Who will ascend into heaven?

(that is [=pesher], to bring Christ down)

Who will descend into the abyss?

(that is, to bring Christ up from the dead).

The word is near you, on your lips and in your heart

(that is, the word of faith which we preach)

Nowhere is Paul's (mis)interpretation of the Old Testament more prominent than here. Even the narrated context of the Deuteronomy text is completely ignored. The Old Testament text is speaking in the present directly about Christ. Below we will return to this text when discussing Paul's understanding of the law. ${ }^{12}$

\section{Promise and Fulfillment}

Paul pronounces explicitly in Romans 1:2 that his gospel regarding Jesus Christ was promised beforehand by the prophets in the holy scriptures. Aspects of this promise are then proved by means of quotations from the OT in Romans, e.g.: Hosea 2:1,15 in Rm 9:25 (Gentiles becoming children of God); Isaiah 28:16 in $\mathrm{Rm} \mathrm{9:33} \mathrm{(the} \mathrm{stumbling} \mathrm{stone} \mathrm{and}$ skandalon to be believed); Isaiah 59:20-21 and 27:9 in Rm 11:26-27 (all Israel will be saved).

12 According to Ellis (1957:) the midrash pesher method is not confined to Qumran and is also to be found in Paul's use of Is 49:8 in 2 Cor 6:2 (the 'day of salvation' of the Isaianic ebed Yahweh is now). 


\section{Paradigmatic Application}

Hahn (2011:198) distinguishes cases where Paul made use of Old Testament examples in a negative or positive sense. In Romans 3:10-18 five references (Ps 14:1-3; 140:3; 10:9; Isa 59:7-8 and Ps 36:2) are chained together to emphatically make the point that none are righteous (not even the Jews). ${ }^{13}$ Positive examples are represented by Paul's use of Psalm 19:5, Deuteronomy 32:21 and Isaiah 65:1 in Romans 10:18-20 to indicate the inclusiveness of salvation. The references to Eliah's despair and the remnant (cf. 1 Kgs 9:14-18 in Rm 11:2-5) can also be regarded to fall into this category. ${ }^{14}$

\section{Paul's Use of Quotations, General References and Allusions}

Paul's use of direct quotations, general references and allusions to the Old Testament indicates that he worked with a written text $(L X X)$, as well as his general knowledge of the Old Testament, thereby allowing him much creativity in developing his thought. ${ }^{15}$

\section{Direct Quotations}

In all his letters Paul quotes the Old Testament about 130 times. All these quotations occur in his four 'main letters' (Romans, Galatians, 1 and 2 Corinthians, the undisputed letters of Philippians, Philemon and 1 Thessalonians not containing any).

About 60 direct quotations occur in the letter to the Romans (about $45 \%$ of the total), distributed fairly evenly across the letter, with no quotations in chapters 6-7 and $16 .{ }^{16}$ The great number can be ascribed to the fact that this letter deals with the core of Paul's theology, (justification by faith instead of the law) and that he wished it to be substantiated by the Old Testament. A further reason can be that Paul as an educated Jew made a major shift in his religion, and the Old Testament was the 'book' of his 'old religion'. For Paul becoming a Christian did not, however, mean a complete rejection of Judaism. For him Christianity is Judaism correctly interpreted. This he had to illustrate by interpreting the Old Testament the way he did.

Directly quoting the Old Testament in a dicta probantia fashion provides an impression of rationalistic thinking in Paul's thought and enhances its rhetorical value. ${ }^{17}$ Reference was made above to Romans 3:14-18 where different texts from different locations are chained together in an attempt to create a powerful argument for why all people are under sin. However, the present day reader should be aware: since the Old Testament context plays but a meagre role in his quotations, the quotations provide more misreadings of the Old Testament than correct readings. Searching for the correct interpretation in the original context of the (Hebrew) texts quoted in Romans, to which otherwise not so much explicit attention would have been paid, serves obviously to the benefit of a better understanding of

13 Referred to by Kümmel (1973:267) as the negative proof of the gospel of grace ("der negative Nachweis der die Rechfertigung durch Glauben allein ermöglichen den Heilstatt Gottes in Christus").

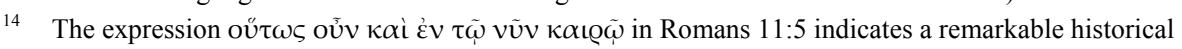
awareness in Paul's thinking, whereas his use of Ps 19 (about the beauty of nature) represents a misreading of the Old Testament text.

15 Conzelmann (1976:188) remarks: "Bei der Verwendung des Alten Testaments hält sich Paulus an kein Schema. Es gibt wörtliche Zitate, freie Variationen, Anspielungen, Aufgreifen von Inhalten: Geboten, Ereignissen, Personen".

16 About 50\% of the Roman quotations appear in chapters 9-11 (dealing with Israel), which is to be expected.

17 To my mind Vorster (1991 and 2009) can add value to his rhetorical analysis of Romans by exploring Paul's quotations of the Old Testament. 
the Old Testament. In the endeavour to save the Old Testament from Paul as it were, the non-fundamentalist Old Testament scholar is forced towards more responsible interpretation, although the latter can only be approached asymptotically.

That Paul's first direct quotation (Hab 2:4) occurs in the theme of the letter ( $\mathrm{Rm} \mathrm{1:17)}$ is

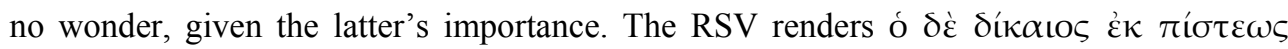

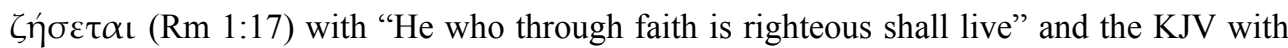

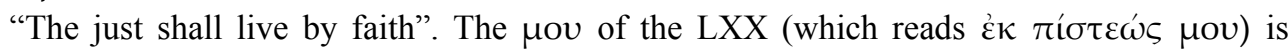

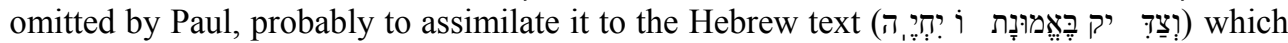
clearly refers to the faith (or rather trust) of the צְִָּ (upright, good person). Although at face value there seems to be nothing wrong with Paul's use of Habakkuk 2:4, this important text is used out of context. From mere superficial reading of Habakkuk 2 it appears clearly that the righteous (who live uprightly and in all probability represents Israel) function in contrast to the Babylonians who are 'puffed up', 'greedy' and 'take captive all the peoples' (Habakkuk 2:5). With Paul's doctrine of justification through faith the Habakkuk text has simply nothing to do.

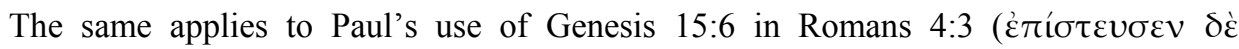

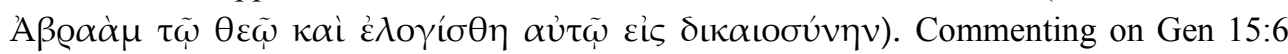

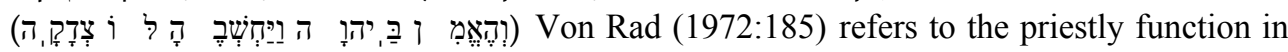

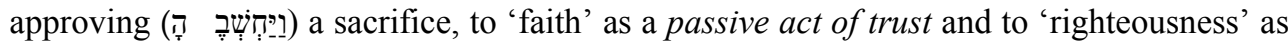
proper conduct.

Let me state clearly: By contrasting the contexts of the original Old Testament text and Paul's use of it, my aim is not to downgrade Paul's idea of justification by faith (which I regard as highly creative), but to prevent that the present-day reader of Genesis 15:6 (whether Jewish or Christian) from reading Genesis 15 with Pauline eyes, thereby silencing the Old Testament text.

\section{General References and Allusions}

Ellis (1957:153) only refers to about 24 Old Testament allusions (two from the Wisdom of Solomon) ${ }^{18}$ in Romans without distinguishing separate references. To my mind general references refer to cases where an Old Testament text is clearly discussed without quoting it (e g Abraham's faith in Rm 4 and the Adam-Christ typology in Rm 5), whereas allusions refer to matters such as circumcision, the law, sacrifices, creation or notions like retribution (cf. Rm 2:6 and Ps 62:13) or their being no respect of persons with God (cf. Rm 2:11 [oủ

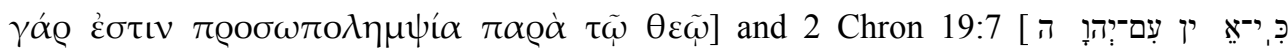

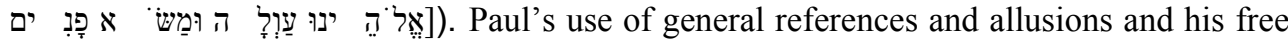
interaction with the scriptural tradition, accounts for much of his creative thinking and also allowed him more scope to explicate his gospel about faith in Christ in terms of the Old Testament. $^{19}$

18 Cf. Rm 1:20-32 and Wisdom 13-14 (on the human failure to see God in creation), as well as Rm 11:32 and Wisdom 11:23 (on God's mercy to all people in view of their ultimate faith).

19 Although I agree with Punt (2000:314-316) that it is often difficult to distinguish between direct quotations and allusions, I nevertheless hope to have indicated from the discussed examples (Punt mentions none) above that such a distinction is indeed possible in most cases. 
Paul's use of the Septuagint, the Hebrew text and Targum

Ellis (1957:150) indicated that in twelve cases Paul quoted the Septuagint where it is in agreement with the Hebrew text and only in 8 cases his quotations from the LXX are contrary to the Hebrew text. In one case (Job 41:3 in Rm 11:35) he is even more in agreement with the Hebrew text. This means that he is at variance with both the Septuagint and the Hebrew text in more than $50 \%$ of his quotations. Interestingly, his variance from the Septuagint and the Hebrew text in quoting Deuteronomy 32:35 in Romans 12:19 can be explained by his making use of the Targum (Ellis 1957:140). By using the Septuagint (which included deuteron-canonical and even pseudo-epigraphical literature) ${ }^{20}$ Paul on the one hand had a wider Old Testament tradition to use. On the other hand, by choosing between different translations and even rendering his own versions, it meant more misreading as far as the original Hebrew Bible is concerned.

One can conclude that in his use of the Old Testament (whether by direct quotation, reference or allusion) Paul most of the time reads the Old Testament out of context. This is due to his reading of the Old Testament in terms of the Christ event. On the other hand, being well versed in the text of the Old Testament, Paul must be credited for paying (at least some times) due attention to the Old Testament text within its literary (narrated) context (e.g. Abraham's faith before circumcision [cf. Gn 15:6 and 17]; the Adam-Christ typology in Rm 5:12-2 and Elijah and the remnant [cf. 2 Ki 19:14-18 in Rm 11:3-4]).

Paul's 'free' use of the Old Testament stimulated his creative thinking. Despite indicating the importance of faith in selected Old Testament passages, Paul's view of justifi-

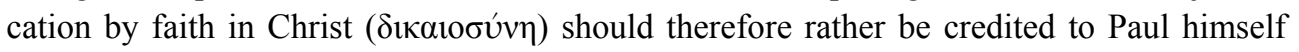
than the Old Testament. The same holds true for his view on creation as a 'proof' for faith in God (if that idea is not borrowed from the Wisdom of Solomon).

\section{Paul's (Mis-)Understanding of the Torah}

A special case (because of its importance for his central doctrine and his understanding of the Old Testament and Israel) is Paul's understanding of the law.

Paul's understanding of the (Mosaic) law appears to be ambivalent. Sometimes he quotes it positively (cf. Gn 15:6 in Rm 4:3), but in general he dismisses it for not being a saving mechanism (e.g. Rm 3:28). As such his views were rather informed by contemporary rabbinic views on the law (cf. Davies 1980; Eichholz 1972:134-260) than on a proper understanding of the Covenant, Deuteronomic and Holiness Codes of the Pentateuch. It is important for the present-day reader to note that the priestly and Deuteronomic laws were originally not meant as saving mechanisms for the individual believer in view of eternal life, but as religiously motivated civil laws meant to regulate ancient Israelite society. ${ }^{21}$ Considering Deuteronomy 30:11-14 again (putting Paul's pesher- exegesis of Rm 10:6-8 in brackets), it becomes clear that the law is appreciated as something extremely positive and possible to do. Interesting is Paul's omission of the words 'to do it' in Romans $8: 10 .^{22}$

20 To the possible allusion to creation in Wisdom 13-14 and God's 'universal' mercy in Wisdom 11 has already been referred above, $\mathrm{cf}$. footnote 18 .

21 Ancient Israel's faith was 'diesseitig' and entertained no eschatology, cf. Zimmerli 1971. For in depth discussions of the function of Israelite law in its original contexts, see Otto 2007 and 2009.

22 The positive nature of the law is off course lauded in the longest Psalm of the Old Testament (Ps 119). 


\section{Paul and Jesus' Use of the Old Testament}

Both Paul (through reading as well as oral memory) and Jesus (most probably only oral memory) used the Old Testament selectively.

The remarks here are not meant to revisit the Paul-Jesus debate (for a short overview, see Hahn 2011:323-329), but are confined to the use of Scripture by both. ${ }^{23}$ Paul used the Old Testament specifically in terms of the Christ event, and therefore often misread it, whereas Jesus of Nazareth appropriated it critically in terms of his view on the kingdom of God with 'human compassion' as the criterion (e.g. the antitheses of the sermon on the mount and the use of Gen 2:24 and criticism of Deut 24:1-4 in the passage on divorce in Mk 10, cf. Scheffler 2011:548). As such (not in principle being bound by contemporary exegetical techniques, nor by the authority of scripture) Jesus' paid more due to the original context of the Old Testament text.

\section{Paul's Non-use of the Old Testament}

Paul had the effect that believers in his gospel do not hear the Old Testament for what it is.

Although Paul quotes and refers to various Old Testament books (about 13), there are many books that do not feature in his thought. Because of his understanding of scripture mainly in terms of the gospel of Christ, large sections of the Old Testament are overlooked. Thereby Paul inhibits his reader to understand and appreciate the Old Testament fully in terms of its rich diversity (cf. Zimmerli 1971). Absent in his thought are (to mention but a few aspects):

- the critical wisdom (theodice problem) of Job and Qohelet (despite his quotation of Job 41:3);

- the positive evaluation of sexuality as expressed in Genesis and Song of songs;

- the political struggle of prophets such as Jeremiah, Ezekiel, Amos and Micah;

- the positive appreciation of nature in the Psalms (e.g. 8, 9, 104 and 139);

- the engagement for the socially marginalized in Deuteronomy, the prophets and the Psalm.

On the other hand Paul's selected use of the Old Testament and his use of contemporary exegetical techniques had the positive effect that violent practices corroborated by the Old Testament such as slavery (cf. Rm 1:1; 6), animal sacrifice (Rm 12:1-2), circumcision (Rm

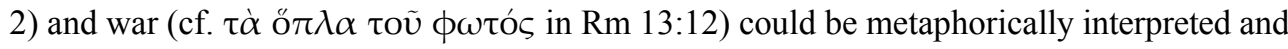
thereby be relativised.

\section{Reading Paul and the Old Testament Empathetically}

Empathetic reading implies reading a text with an open mind, appreciating it and accepting it in terms of what it wishes to communicate, without necessarily appropriating it.

\section{Reading Paul empathetically}

To my mind critically scrutinising Paul's use of the Old Testament (to foster his gospel about Christ) can contribute to understanding that message better. Paul's positive message is not nullified by his misreading of the Old Testament and may still be appropriated. This, however, does not imply that his method of Old Testament reading should serve as an exegetical model for present-day Old Testament scholars - to the contrary.

23 For Jesus' use of Scripture, see Moyise 2010 and Scheffler 2011. 


\section{Reading the Old Testament empathetically}

Reading the Old Testament emphatically also implies reading it for what it wishes to communicate itself, without the veil which Paul (ironically) drew over it. It means to appreciate it in its rich diversity covering all areas of human life, even as a collective debate of often conflicting views. After paying due attention to the messages of the Old Testament in a variety of contexts, a present-day reader may also appropriate the Old Testament selectively. To my mind Jesus' propagation of love and 'compassion' (cf. Lk 6:36; Mt 22:40) represents a valid criterion for reading any religious text in the context of the needs of today's world.

\section{Conclusion}

To conclude with a somewhat hyperbolical statement: One cannot fully understand Paul's letter to the Romans if one doesn't understand how he used the Old Testament incorrectly.

Whether my reflections above would have contributed to a better understanding of Paul's letter to the Romans, as well as the Old Testament, is for every individual reader to decide. I can only testify that in my own case, comparing the use of a variety of Old Testament texts by Paul with the original function of the same texts in their original context(s), had that desired effect. New Testament scholars too soon 'defend' Paul's reading by asserting that he was a child of his time and should not be judged on the way he read the Old Testament. ${ }^{24}$ However, by being aware of Paul's method and comparing Old Testament texts in their original contexts with Paul's use of them provides a relief against which both can be better understood. Reflecting on further examples will surely emphasise the point. Prominent scholars from both the subjects of Old and New Testament have failed to be instructed by an awareness of the differences between the Old Testament and Paul's reading of it, thereby actually internalising Paul's view of the Tanach as Old Testament (e.g. Bultmann [1993] 2002). ${ }^{25}$ Ironically, by being apologetic of Paul's reading and use, Paul himself is being done a disservice (for failing to understand him better). Moreover, by adopting Paul's view of Scripture the Old Testament in all its rich diversity is not only misunderstood, but actually silenced - ironically also to the disadvantage to its present-day readers.

The Old Testament is supported by the major three Abrahamitic religions. However, Judaism, Christianity and Islam live in conflict in today's world and this conflict actually constitutes a threat to world peace. The simple message of love and peace which Jesus of Nazareth preached (which he obtained from the Old Testament and which even Paul proclaims), ${ }^{26}$ cf. Rm 12:18-21; 13:8-10; cf. De Villiers 2011) is also positively appropriated by all three religions. But in practice it fails. Scholarship owes it to the world that the consensus which it can and indeed distinguish at a scholarly level (or the open dialogue when there is difference) be passed on to all levels of society. For Christians it means the abandonment of the Pauline view of the Old Testament and appropriating the grace of the latter's richness. ${ }^{27}$

24 Bornkamm (1971:128) to my mind too quickly dismisses HJ Schoeps's (1959) view that Paul did not give due place to the Old Testament's view of the law as 'covenant law and gift of grace'. To my mind Jewish scholars's (such as Schoeps) engagement with Paul should rather be welcomed and made fruitful for Jewish-Christian dialogue.

25 Cf. the remark by Jonker 1983:23: "The gospel which Paul preaches is moreover the only true interpretation of what the Old Testament means to say" (translated from Afrikaans).

26 Cf. Rm 12:18-21; 13:8-10; cf. De Villiers 2011.

27 Or to put it differently: if the religion of Jesus (with its expressed inclusivity, cf. Mt 8:11; Lk 13:29-30) could foster dialogue with Judaism and Islam, such a dialogue should not be jeopardised by regarding Paul's kerugma as a sine qua non for common understanding. 


\section{BIBLIOGRAPHY}

Althaus, P 1970. Der Brief an die Römer. 11. Aufl. Göttingen: Vandenhoeck \& Ruprecht.

Barret, CK 1970. The interpretation of the Old Testament in the New, in Ackroyd, PR \& Evans, CF (eds.), The Cambridge history of the Bible. Volume 1. From the beginnings to Jerome, 377-411. Cambridge: Cambridge University Press.

Barth, K [1921] 1960. The epistle to the Romans. London: Oxford University Press.

Borg, MJ \& Crossan, JD 2009. The first Paul: Reclaiming the radical visionary behind the Church's conservative icon. London: SPCK.

Bornkamm, G 1970. Paulus. 2. Aufl. Stuttgart: Kohlhammer.

Bornkamm, G 1971. Paul. Translated by DMG Stalker. London: Hodder and Stoughton.

Breytenbach, 2011.The reception of Paul's letter to the Romans. Paper read at conference at University of Pretoria on 22 September 2011 in celebration of AB du Toit's $80^{\text {th }}$ birthday.

Bultmann, R [1933] 2002. Die Bedeutung des Alten Testaments für den christlichen Glauben, Bultmann 2002:148-171.

Bultmann, R 2002. Neues Testament und christliche Existenz: Theologische Aufsätze, ausgewählt, eingeleitet und herausgegeben von Andreas Lindemann. Tübingen: Mohr Siebeck.

Colenso, JW [1861] 2003. Commentary on Romans (ed. by JA Draper). Pietermaritzburg: Cluster Publications.

Conzelmann, H 1976. Grundriss der Theologie des Neuen Testaments.München: Kaiser Verlag.

Davies, WD 1980. Paul and rabbinic Judaism. Some rabbinic elements in Pauline theology, $4^{\text {th }}$ ed. Philadelphia: Fortress Press.

De Villiers, P 2011. Love in Romans. Paper read at conference at University of Pretoria on 22 September 2011 in celebration of AB du Toit's $80^{\text {th }}$ birthday.

Du Toit, AB 2000. A tale of two cities: "Tarsus or Jerusalem" revisited. NTS 46:375402.

Du Toit, AB 2006. Shaping a Christian lifestyle in the Roman capital, in Van der Watt, JG (ed.), Identity, ethics, and ethos in the New Testament, 167-197. Berlin: De Gruyter (BZNW 141).

Eichholz, G 1972. Die Teologie des Paulus im Umriss. Neukirchen-Vluyn: Neukirchener Verlag.

Ellis, EE 1957. Paul's use of the Old Testament. Edinburgh: Oliver and Boyd.

Fitzmyer, J 1993. Romans. New York: Doubleday. (AB 33.)

Hahn, F 2011. Theologie des Neuen Testaments: Bd I: Die Vielfalt des Neuen Testaments. 3. Aufl. Tübingen: Mohr Siebeck.

Hill, CC 2001. Romans, in Barton, J \& Muddiman, J (eds.), The Oxford Bible Commentary, 1083-1108. Oxford: Oxford University Press. 
Le Roux, JH 1991. God het die ryke ook lief: 'n Allegoriese lees van die Ou Testament, in Bosman, HL, Gous, IGP, Spangenberg, IJJ (reds.), Purper en flenterlap: Rykdom en armoede in die Ou Testament, 90-101. Pretoria: Van Schaik.

Jonker, WD 1983. Die brief aan die Romeine. Vyfde druk. Kaapstad: NG KerkUitgewers.

Kümmel, WG 1973. Einleitung in das Neue Testament. Heidelberg: Quelle \& Meyer.

Michel, O [1929] 1972. Paulus und seine Bibel. Darmstadt: Wissenschaftliche Buchgesellschaft.

Moyise, S 2010. Jesus and Scripture. London: SPCK.

Otto, E 2007. Das Gesetz des Mose. Darmstadt: Wissenschaftliche Buchgesellschaft.

Otto, E 2009. Die Torah: Studien zum Pentateuch: Gesammelte Schriften. Wiesbaden: Harrassowitz Verlag.

Punt, J 1996. Paul, Hermeneutics and the Scriptures of Israel. Neotestamentica 30 (2), 377-425.

Punt, J 2000. Paul and the Scriptures of Israel: How much hermeneutical awareness did he display? Neotestamentica 2000, 34(2), 11-327.

Reumann, J 2003. Romans, in Dunn, JDG \& Rogerson, JW (eds.), Eerdmans commentary on the Bible, 1277-1313. Cambridge: Eerdmans.

Ridderbos, H 1973. Paulus: Ontwerp van zijntheologie. Kampen: JH Kok.

Scheffler, EH 1991. Goeie nuus aan die armes: Die Nuwe Testament se gebruik van die Oue, in Bosman, HL, Gous, IGP, Spangenberg, IJJ (reds.), Purper en flenterlap: Rykdom en armoede in die Ou Testament, 102-114. Pretoria: Van Schaik.

Scheffler, EH 2011. (The Markanan Matthean) Jesus' appropriation and criticism of the Torah: The question of divorce. HTS 67(1), 545-550.

Schlier, H 1977. Der Römerbrief. Freiburg: Herder. (HTKNT 6.)

Schmidt, HW 1972. Der Brief des Paulus an die Römer. 3. Aufl. Berlin: Evangelische Verlaganstalt. (ThHNT 6.)

Schnelle, U 2007. Einleitung in das Neue Testament.6. Neubearbeitete Auflage. Göttingen: Vandenhoeck \& Ruprecht.

Schoeps, HJ 1959. Paulus: Die Theologie des Apostels im Lichte der Jüdischen Religionsgeschichte. Tübingen: JCB Mohr.

Schoeps, HJ 1961. Paul: The theology of the apostle in the light of Jewish religious history. Translated by H Knight. Philadelphia: Westminster Press.

Schrenk, G 1985. s v dikaiosune, ThWNT (abridged in one volume by GW Bromily).

Von Rad, G 1972. Genesis: A Commentary. $3^{\text {rd }}$ rev. ed. London: SCM.

Vorster, JN 1991. Die Mag van God, nou ook vir die heidene, in Roberts, JH, Vorster, WS, Vorster, JN \& Van der Watt, JG (reds.), Teologie in konteks, 156-186. Halfway House: Orion.

Vorster, JN 2009. Rhetorical criticism, in Du Toit, AB (ed.), Focussing on the message: New Testament hermeneutics, exegesis and methods, 505-578. Pretoria: Protea Book House. 
Westermann, C 1981. Genesis: 2. Teilband: Genesis 12-36. Neukirchen-Vluyn: Neukirchener Verlag.

Zimmerli, W 1971. Die Weltlichkeit des Alten Testaments. Göttingen: Vandenhoeck \& Ruprecht. 